\title{
PENGARUH MODEL PEMBELAJARAN KOOPERATIF TIPE THINK TALK WRITE (TTW) TERHADAP KEAKTIFAN BELAJAR SISWA DALAM PEMBELAJARAN MATEMATIKA KELAS IV SDM 020 KUOK
}

\author{
Muhammad Syahrul Rizal \\ Universitas Pahlawan Tuanku Tambusai, Jl. Tuanku Tambusai, No 23 Bangkinang \\ E-mail: rizal.universitaspahlawan@gmail.com
}

\begin{abstract}
This research aims to analyze the influence of cooperative learning model types Think Talk Write (TTW) against the liveliness of the grade IV SD study conducted in SDM 020 Kuok Kampar to the subject of research is the grade IVa as a class experimentation and grade $1 \mathrm{Vb}$ as class control in learning 2017/2018. This type of research is research conducted experiments with design research on non equivalent control group design.The instruments used in the penelitia this is the observation sheet the liveliness of student learning.Data research results may indicate thitung (21.179) > ttabel $(1,682)$, this means there are differences the liveliness of students.After holding of treatment and done posttest, experimental class students may be higher compared to the control class.So, there's the influence of model learning TTW against liveliness student learning.So, there's the influence of model learning student learning outcomes against TTW. Based on the results of data analysis, it can be concluded that cooperative learning model type affects liveliness TTW students significantly.
\end{abstract}

Keywords: Cooperative learning model types Think Talk Write (TTW), liveness of the students

\begin{abstract}
Abstrak
Penelitian ini bertujuan untuk menganalisa pengaruh model pembelajaran kooperatif tipe Think Talk Write (TTW) terhadap keaktifan siswa kelas IV SD Penelitian ini dilakukan di SDM 020 Kuok Kampar dengan subjek penelitian adalah siswa kelas IVa sebagai kelas eksperimen dan siswa kelas IVb sebagai kelas control pada tahun pembelajaran 2017/2018. Jenis penelitian yang dilakukan adalah penelitian eksperimen dengan desain penelitian non equivalent control group design.Instrumen yang digunakan dalam penelitia ini adalah lembar observasi keaktifan belajar siswa.Data hasil penelitian keaktifan menunjukkan $t_{\text {hitung }}(21,179)>t_{\text {tabel }}(1.682)$, hal ini berarti ada perbedaan keaktifan siswa. Setelah diadakannya treatment dan dilakukan posttest, keaktifan siswa kelas eksperimen lebih tinggi dibandingkan dengan kelas control. Jadi, ada pengaruh model pembelajaran TTW terhadap keaktifan belajar siswa. adi, ada pengaruh model pembelajaran TTW terhadap hasil belajar siswa. Berdasarkan hasil analisis data, dapat disimpulkan bahwa model pembelajaran kooperatif tipe TTW berpengaruh terhadap keaktifan siswa secara signifikan.
\end{abstract}

Kata Kunci: Model pembelajaran kooperatif tipe Think Talk Write (TTW), keaktifan siswa

Pendidikan merupakan suatu kegiatan pokok bagi anak-anak untuk mempersiapkan kehidupan hari ini dan masa mendatang, pendidikan menentukan bagaimana kualitas seseorang didalam kehidupan sosial bermasyarakat. John Dewey (dalam Sagala, 2011:3), menyatakan bahwa pendidikan merupakan suatu proses pembentukan kemampuan dasar yang fundamental, baik yang menyangkut daya pikir atau daya intelektual. Maupun daya emosional atau perasaan yang diarahkan kepada tabiat manusia dan kepada sesamanya.Dapat kita ketahui bahwasanya pendidikan merupakan usaha yang terbentuk melalui pembelajaran dalam mengembangkan intelektual pembinaan kepribadian anak. Dalam UU SISDIKNAS No.20 tahun 2003, pendidikan merupakan suatu usaha yang dilakukan secara sadar dan terencana untuk mewujudkan suasana dan proses pembelajaran agar peserta didik secara aktif mampu mengembangkan potensi yang ada didalam dirinya untuk memiliki 
kekuatan spiritual keagamaan, kepribadian yang baik, pengendalian diri berakhlak mulia, kecerdasan, dan keterampilan yang diperlukan oleh dirinya dan masyarakat.

Matematika merupakan suatu mata pelajaran yang mempunyai peranan yang sangat luas dalam kehidupan manusia. Salah satunya matematika merupakan ilmu yang mendasari perkembangan teknologi modern dan mempunyai peran penting dalam berbagai disiplin ilmu dalam mengembangkan daya pikir manusia. Matematika membekali peserta didik untuk mempunyai kemampuan berfikir logis, analitis, sistematis, kritis serta kemampuan bekerja sama. Oleh sebab itu, pelajaran matematika perlu diberikan kepada semua peserta didik dimulai dari sekolah dasar (Depdiknas, 2006).Hal ini sejalan dengan tujuan pembelajaran matematika di sekolah dasar agar peserta didik memiliki kemampuan, yaitu (1) Memahami konsep matematika, menjelaskan keterkaitan antar konsep dan mengaplikasikan konsep, secara luwes, akurat, efisien, dan tepat, dalam pemecahan masalah; (2) Menggunakan penalaran pada pola dan sifat, melakukan manipulasi matematika dalam membuat generalisasi, menyusun bukti, atau menjelaskan gagasan dan pernyataan matematika; (3) Memecahkan masalah yang meliputi kemampuan memahami masalah, merancang model matematika, menyelesaikan model dan menafsirkan solusi yang diperoleh; (4) Mengkomunikasikan gagasan dengan simbol, tabel, diagram, atau media lain untuk memperjelas keadaan atau masalah; (5) Memiliki sikap menghargai kegunaan matematika dalam kehidupan, yaitu memiliki rasa ingin tahu, perhatian, dan minat dalam mempelajari matematika, serta sikap ulet dan percaya diri dalam pemecahan masalah. (Depdiknas, 2006).

Untuk memenuhi tujuan tersebut, seorang guru hendaknya merencanakan suatu pembelajaran yang aktif dan bermakna bagi peserta didik agar mereka mampu memahami apa yang dipelajari serta bersemangat dalam proses belajar mengajar di kelas. Guru bisa mengembangkan pembelajarannya dengan menggunakan metode-metode atau model-model pembelajaran yang aktif dan inovatif sehingga peserta didik akan lebih terpacu dan bersemangat ketika proses belajarmengajar sedang berlansung di kelas. Hasil pengamatan peneliti pada tanggal 22 Januari 2018 di sekolah dasar di daerah Kuok provinsi Riau, pada proses pembelajaran Matematika dapat disimpulkan kurang menarik dan kurang efektif bagi peserta didik sehingga mereka menjadi bosan ketika proses pembelajaran berlangsung. Pembelajaran Matematika yang dilakukan masih bersifat konvensional (teacher centered). Guru masih sangat sering berceramah tanpa melibatkan siswa, Matematika bukan suatu pengetahuan yang bisa dipindahkan begitu saja dari guru kepada siswanya, akan tetapi perlu pembiasaan secara aktif dalam pembelajaran dan melibatkan siswa untuk memperoleh pengetahuan yang sama bahkan lebih dari pengetahuan yang dimiliki oleh gurunya. Pada dasarnya guru hanya menjelaskan secara konseptual tentang materi pembelajaran tanpa mengaitkan materi dengan kehidupan sehari-hari siswa.

Selain itu, pada saat proses pembelajaran berlangsung guru juga tidak melaksanakan atau melakukan kegiatan berkelompok. Padahal jika kegiatan berkelompok dalam proses pembelajaran dimulai dari usia peserta didik, untuk lebih aktif dalam proses pembelajaran maka akan membentuk 
peserta didik menjadi masyarakat yang lebih mandiri dan aktif dalam kegiatan bermasyarakat. Karena tidak membuat siswa aktif dalam proses pembelajaran maka di kelas kondisi sebagian besar siswa terlihat pasif, siswa cenderung hanya duduk, mendengarkan, dan mencatat apa yang disampaikan oleh guru, sehingga dapat dilihat para siswa tidak memiliki keaktifan dalam proses pembelajaran. Dapat diperhatikan juga ketika guru menyampaikan pertanyaan kepada siswa selama berlangsungnya proses pembelajaran, hanya beberapa orang yang bisa menjawab pertanyaan guru tersebut namun kebanyakan siswa ada yang menjawab "tidak tahu buk", ada yang diam saja dan ada yang menundukkan kepalanya, pembelajaran seperti ini disebut konvensional dan akan menyebabkan rendahnya hasil belajar siswa.

Beradasarkan permasalahan tersebut perlu adanya suatu kondisi yang inovatif dalam lingkungan kelas untuk mendukung pembelajaran yang menarik, asyik, dan menyenangkan dan juga perlu adanya pembaharuan serta perbaikan dalam pembelajaran dimana guru sebagai fasilitator dan motivator dalam melakukan perubahan dan perbaikan proses pembelajaran Matematika. Dalam penelitian ini.Peneliti menawarkan solusi dengan menggunakan model pembelajaran kooperatif tipe TTW. Karena model ini menuntut siswa untuk berpikir lebih mandiri dan berdiskusi dan pembelajaran kooperatif tipe TTW ini dapat melatih siswa untuk meningkatkan keaktifan dalam proses pembelajaran.

Model pembelajaran think talk write (TTW) merupakan perencanaan dan tindakan yang cermat mengenai kegiatan pembelajaran, yaitu melalui kegiatan berfikir (think), aktivitas berfikir (think) dapat dilihat dari proses membaca suatu teks bacaan, suatu materi pembelajaran kemudian membuat catatan apa yang telah dibaca. Dalam tahap ini siswa secara individu memikirkan kemungkinan jawaban (strategi penyelesaian), membuat catatan apa yang telah dibaca, baik itu berupa apa yang diketahuinya, maupun langkah-langkah dalam penyelesaian dalam bahasanya sendiri. Setelah tahap think selsai dilanjutkan dengan tahap berikutnya talk, yaitu berkomunikasi dengan mengunakan kata-kata dan bahasa yang mereka pahami. Fase berkomunikasi (talk) pada strategi ini memungkinkan siswa untuk terampil berbicara dan merupakan sarana untuk mengungkapkan dan merefleksikan pikiran siswa.

Harapannya, ketika guru menerapkan model kooperatif tipe TTW (Think Talk Write) ini dalam pembelajaran Matematika maka dapat meningkatkan keaktifan dan hasil belajar siswa. Maka peneliti akan menyimpulkan penelitian ini dengan judul "Pengaruh model pembelajaran kooperatif tipe TTW terhadap keaktifan pada mata pelajaran Matematika Kelas IV Sekolah Dasar"

\section{METODE}

Jenis penilitian yang digunakan dalam penelitian tentang "Pengaruh Model Pembelajaran Kooperatif Tipe Think Talk Write (TTW) Terhadap Keaktifan Matematika Siswa Kelas IV Sekolah Dasar" adalah jenis penelitian eksperimen.Dimana dalam penelitian ini terdapat dua variable, yaitu variabel independent (bebas) dan variabel dependent (terikat). 
Jenis penelitian ini termasuk dalam jenis penelitian kuantitatif yang bertujuan untuk mengukur pengaruh variabel bebas yaitu penggunaan model pembelajaran Think Talk Write (X) terhadap variabel terikat yaitu keaktifan belajar (Y1).

\section{A. Rancangan Penelitian}

Rancangan penelitian yang digunakan adalah eksperimen yang memiliki tujuan untuk mengungkapkan hubungan sebab akibat antar variabel.Penentuan populasi tidak dilakukan secara acak didasarkan pada kemampuan anak. Dengan teknik penelitian non-equivalent control groupdesign yang mempunyai dua kelompok yaitu kelompok control dan kelompok eksperimen. Kelompok Kontrol ini nantinya yang akan menjadi pembanding kelompok eksperimen, kelompok eksperimen akan diberikan perlakuan sehingga akan didapat hasil yang akan dibandingkan dengan kelompok control.

Desain penelitian yang akan digunakan Quasy ExperimentalDesign, jadi setelah ditentukannya kelompok control dan kelompok eksperimen maka pengambilan data dilakukan dengan memberikan pretest pada kedua kelompok yang dilaksanakan pada awal sebelum diberikannya perlakuan pada kelompok eksperimen untuk mengetahui kemampuan awal dari kedua kelompok dan memberikan posttest pada kedua kelompok setelah kelompok eksperimen diberikan perlakuan untuk mengetahui pengaruh pemberian perlkuan tersebut terhadap aktivitas siswa.

\section{B. Subjek dan Waktu Penelitian}

Pada penenelitian ini, subjek yang digunakan adalah siswa kelas IV SDM 020 Kuok, yang terletak di Jl. Gemas Kecamatan Kuok Kabupaten Kampar.Sedangkan sampel penelitian adalah 20 siswa untuk masuk kelas kontrol dan 20 Siswa untuk masuk Kelas eksperimen. Waktu untuk penelitian ini akan dilakukan \pm 1 bulan pada semester genap pada tahun pelajaran 2017/2018.

\section{Teknik Pengumpulan Data}

Teknik pengumpulan data adalah cara yang digunakan untuk mengumpulkan data. Pada penelitian ini, peneliti menggunakan teknik pengumpulan data, sebagai berikut :

\section{Observasi}

Observasi adalah pengamatan yang dilakukan dengan memperhatikan gejala-gejala psikis untuk pencatatan data. Penggunanaan dengan menggunakan teknik observasi ini dilaksanakan ketika proses belajar mengajar yang sedang berlangsung didalam kelas. Kegunaan teknik ini adalah untuk mengamati keaktifan siswa dalam proses pembelajaran di kelas. Keaktifan yang diamati diantaranya adalah visual activities, oral activities, listening activities, writing activities, mental activities dan emotional activities.

\section{Dokumentasi}

Teknik ini digunakan oleh peneliti untuk mendukung pembuktian keabsahan dalam pelaksanaan penelitian. 


\section{Instrumen Penelitian}

Pada penelitian yang akan dilakukan, peneliti akan menggunakan instrument berupa lembar observasi dan lembar tes objektif.

\section{Lembar Observasi Keaktifan Siswa}

Lembar observasi digunakan untuk memperoleh data keaktifan siswa selama proses pembelajaran dengan menggunakan model pembelajaran Think Talk Write (TTW). Diberikannya lembar observasi ini kepada kelomppok Kontrol dan kelompok eksperimen maka akan dapat diketahui perbedaan keaktifan antara kelompok kontrol dan kelompok eksperimen. Jadi akan dapat diketahui bagaimana pengaruh model pembelajaran kooperatif tipe Think Talk Write (TTW) terhadap keaktifan siswa.

\section{E. Teknik Analisis data}

\section{Analisis Data Keaktifan Siswa}

Pengamatan terhada kegiatan pembelajaran ini dilakukan oleh dua orang pengamat. Data hasil pengamatan aktivitas siswa, selama KBM berlangsung dianalisis dengan menggunakan rumus sebagai berikut :

$$
P=\frac{f}{N} x 100 \%
$$

Kategori :

$\mathrm{P} \quad=$ Persentase

$\mathrm{F} \quad=$ Skor rata-rata keaktifan

$\mathrm{N}=$ Jumlah $\quad$ keseluruhan $\quad$ keaktifan yang dinilai (Indarti,2008:76)

Kriteria penilaian keaktifan sebagai berikut :

$$
\begin{array}{ll}
0 \%-19 \% & =\text { Sangat Rendah } \\
20 \%-39 \% & =\text { Rendah } \\
40 \%-59 \% & =\text { Sedang } \\
60 \%-79 \% & =\text { Tinggi } \\
80 \%-100 \% & =\text { Sangat Tinggi }
\end{array}
$$

\section{Analisis Data Hasil Belajar}

Analisis data hasil belajar dihitung dari pengerjaan lembar penilaian hari posttest siswa, dengan rumus sebagai berikut :

$$
\text { Skor Ketercapaian }=\frac{\text { Total skor yang diperoleh }}{\text { Skor maksimal }} \times 100
$$

Kriteria Penilaian:

90-100= Sangat Baik

$70-89=$ Baik 


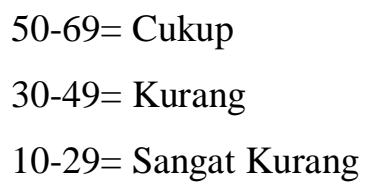

\section{F. Uji Validitas dan Reliabelitas Instrumen}

\section{Uji Validitas}

Menurut Arikunto (2010:168) validitas merupakan suatu ukuran yang menunjukkan tingkattingkat kevalidan atau kesahihan suatu instrumen. Instrumen yang valid akan mempunyai validitas tinggi dan sebaliknya instrumen yang kurang valid berarti memiliki validitas yang rendah. Penelitian ini, dalam mengukur valid atau tidaknya soal dan kelayakan instrumen observasi yang akan dijadikan sebagai instrumen penelitian. Peneliti dalam hal ini mengujicobakan instrumen terlebih dahulu kepada siswa diluar sampel penelitian.Validitas ini dicari dengan menggunakan bantuan SPSS 21.0 dengan Correlate. Dengan kaidah keputusan jika $r_{\text {hitung }}>r_{\text {tabel }}$ maka item soal dikatakan valid.

\section{Uji Reliabelitas}

Apabila alat ukur suatu gejala menunjukkan hasil yang sama diwaktu yang berlainan maka alat ukur tersebut dapat dikatan reliable. Uji releabilitas ini digunakan untuk menghitung uji releabilitas instrumen observasi keaktifan dan item soal seluruh tes.Perhitungan reliabilitas ini menggunakan bantuan SPSS 21.0 dengan uji reliability.(Sumber : Arikunto, 2010:319) Kriteria yang digunakan dalam menentukan reliabilitas instrumen adalah reliabilitas di atas 0,600.Berarti suatu instrumen dikatakan reliable apabila mempunyai nilai koefisien Alpha Cronbach's sekurang-kurangnya 0,600

\section{G. Pengujian Hipotesis}

Hipotesis penelitian adalah jawaban sementara terhadap rumusan masalah penelitian. Pengujian hipotesis ini digunakan untuk membandingkan antara kelas kontrol dan eksperimen, apakah terdapat pengaruh aktivitas belajar terhadap kelas eksperimen setelah diberikan tindakan. Setelah melakukan uji normalitas dan uji homogenitas maka langkah selanjutnya adalah menguji hipotesis.

Analisis yang digunakan untuk menguji hasil belajar dari pengaruh pembelajaran menggunakan model pembelajaran kooperatif TTW dan model pembelajaran konvensional yang dilakukan dengan analisis statistik inferensial.Statistik yang di gunakan adalah uji t (indepent sample $t$ test) untuk mengetahui apakah pembelajaran menggunakan model pembelajaran TTW lebih baik dari pada model pembelajaran konvensional.Hasil tersebut diuji denganperumusan statistik menggunakan program SPSS versi 21.00 for windows.

Adapun menurut Sugiyono (2012:230) dasar pengambilan keputusannya yaitu :

a. Jika $t_{\text {hitung }}$ lebih besar dari $t_{\text {tabel }}\left(t_{\text {hitung }}>t_{\text {tabel }}\right)$ maka hipotesis nihil (Ho) yang diajukan ditolak dan hipotesis alternative (Ha) diterima 
b. Jika $t_{\text {hitung }}$ lebih kecil dari $t_{\text {tabel }}\left(t_{\text {hitung }}<t_{\text {tabel }}\right)$ maka hipotesis nihil (Ho) yang diajukan diterima dan hipotesis alternative (Ha) ditolak

\section{HASIL DAN PEMBAHASAN}

\section{A. Uji Instrumen Penelitian}

Uji instrument penelitian terdiri dari uji validitas dan reliabilitas.Adapun data yang digunakan untuk uji validitas dan reliabilitas dalam penelitian ini adalah hasil observasi Keaktifan Belajar Siswa pada mata pelajaran Matematika siswa kelas IV SDM 020 Kuok yang berjumlah 20 anak. Uji validitas instrument penelitian menggunakan korelasi product moment dengan bantuan program SPSS 17 for windows.

Sugiyono (2010: 121) mengatakan bahwa uji validitas merupakan suatu langkah pengujian yang dilakukan terhadap isi (content) dari suatu instumen, dengan tujuan untuk mengukur ketepatan instrumen yang digunakan dalam suatu penelitian. Tinggi rendahnya validitas instrumen menunjukkan sejauh mana data yang terkumpul tidak menyimpang dari gambaran validitas yang dimaksud.

Uji validitas instrumen penelitian dilakukan dengan menganalisis hubungan antar skor setiap butir soal dengan total skor.Sugiyono (2010:363) rumus korelasi yang dapat digunakan adalah yang dikemukakan oleh pearson, yang dikenal dengan rumus Korelasi Product Moment sebagai berikut:

$$
\begin{aligned}
& \mathrm{r}_{\mathrm{xy}}=\mathrm{N} \Sigma \mathrm{XY}-(\Sigma \mathrm{X})(\Sigma \mathrm{Y}) \\
& \sqrt{ }\left\{\mathrm{N} \Sigma \overline{\left.\mathrm{X}^{2}-\left(\Sigma \mathrm{X}^{2}\right)\right\}\left\{\mathrm{N} \Sigma \mathrm{Y}^{2}-\left(\Sigma \mathrm{Y}^{2}\right)\right\}}\right.
\end{aligned}
$$

Keterangan: $r_{x y}$ : pengaruh variabel $\mathrm{X}$ dan $\mathrm{Y}$

$\Sigma \mathrm{X}$ : jumlah seluruh skor item

$\Sigma Y$ : jumlah seluruh skor total

$\mathrm{N}$ : jumlah responden

Kriteria pengujian validitas instrumen dengan cara membandingkan $r$ tabel dengan $r$ hitung. Jika $r$ hitung $>r$ tabel berarti butir soal valid, dan apabila $r$ hitung $<r$ tabel berarti butir soal tidak valid. Uji validitas angket penelitian dilakukan pada mata pelajaran IPS Siswa kelas IV SDM 020 Kuok.Jadi uji validitas angket penelitian disebar ke dua puluh siswa kelas IV SDM 020 Kuok, hasil rekapitulasi jawaban angket dapat dilihat pada lampiran 2. Selanjutnya hasil uji validitas masing-masing variabel akan diuraikan sebagai berikut

\begin{tabular}{lccc}
\hline $\begin{array}{c}\text { Indikator } \\
\text { Keaktifan Belajar Siswa Akademis }\end{array}$ & Koefisien Korelasi (r hitung) & $\mathbf{P}$ & Keterangan \\
VA & 0.812 & 0,000 & \\
OA & 0.710 & 0,000 & Valid \\
LA & 0.680 & 0,002 & Valid \\
WA & 0.712 & 0,000 & Valid \\
MA & 0.787 & 0,001 & Valid \\
EA & 0.663 & 0,000 & Valid \\
\hline
\end{tabular}


Hasil uji validitas di atas menunjukkan bahwa signifikan $r$ hitung $<0.05$, maka seluruh butir soal variabel Keaktifan Belajar Siswa dinyatakan valid.Dengan demikian dapat diketahui bahwa semua pernyataan/indikator pada variabel Keaktifan Belajar Siswaakademis adalah valid.

Uji selanjutnya adalah uji reliabilitas, yaitu uji yang dilakukan terkait ketetapan atau keajegan suaru instrument penelitian dalam menilai apa yang dinilainya (Arikunto, 2010 : 90). Artinya, kapanpun instrumen penilaian tersebut digunakan akan memberikan hasil yang relatif sama. Adapun hasil uji reliabilitas dari variabel prestasi akademisbelajar adalah:

\section{Variabel Penelitian}

Keaktifan Belajar Siswa Akademis

\section{Alpha Cronbach's}

0.858

Hasil uji reliabilitas pada variabel Keaktifan Belajar Siswa akademis dan Hasil Belajar menghasilkan nilai alpha cronbach's lebih dari 0,60. Dengan demikian dapat diketahui bahwa variabel Keaktifan Belajar Siswa akademis dalam penelitian ini adalah reliabel.

\section{B. Deskripsi Variabel Penelitian}

Variabel Keaktifan Belajar Siswa yang diukurdari 5 (lima) indikator dan Hasil Belajar yang diukur dari 15 soal, dimana masing-masing indikator tersebut ada5 (lima) skala penilaian yaitu:

Keaktifan Siswa :

$$
\begin{array}{ll}
\text { Skor } 1=\text { Sangat Rendah } & =0 \%-19 \% \\
\text { Skor } 2=\text { Rendah } & =20 \%-39 \% \\
\text { Skor } 3=\text { Sedang } & =40 \%-59 \% \\
\text { Skor } 4=\text { Tinggi } & =60 \%-79 \% \\
\text { Skor 5 }=\text { SangatTinggi } & =80 \%-100 \%
\end{array}
$$

Analisis deskriptif digunakan untuk mendeskripsikan keadaan variabel itu sendiri. Analisis ini dilakukan dengan cara menjelaskan keadaan variabel Keaktifan Belajar Siswa dan Hasil Belajar siswa kelas IV SDM 020 Kuok pada mata pelajaran Matematika, dengan jumlah 22 anak di kelompok kontrol dan 22 anak di kelompok eksperimen. berikut:

Adapun deskripsi hasil dari variabel Keaktifan Belajar Siswa akademis adalah sebagai

\section{Hasil Keaktifan Belajar SiswaAkademis pada Kelompok Kontrol dan Eksperimen}

Distribusi frekuensi kemampuan anak dilihat dari Keaktifan Siswa dalam belajar akademis yaitu sebagai berikut:

Tabel 4.6

Keaktifan Belajar Siswa akademis Akademis pada Kelompok Kontrol dan Eksperimen

\begin{tabular}{lrrrrr}
\hline & & \multicolumn{2}{c}{ Keaktifan } & \multicolumn{2}{c}{ Total } \\
\cline { 3 - 5 } & & Sedang & \multicolumn{2}{c}{ Sangat Tinggi } & \\
\hline Kelompok & Kontrol & 22 & 0 & 22 \\
& & $100 \%$ & $0 \%$ & $100 \%$ \\
\hline
\end{tabular}




\begin{tabular}{lrrrr}
\hline & Eksperimen & 0 & 22 & 22 \\
& $0 \%$ & $100 \%$ & $100 \%$ \\
\hline Total & 22 & 22 & 44 \\
& $50.0 \%$ & $50.0 \%$ & $100 \%$ \\
\hline
\end{tabular}

\section{Sumber:Data yang sudah diolah}

Hasil pengamatan pada tabel 4.6 keaktifan siswa pada kelompok kontrol mayoritas menunjukkan bahwa 22siswa $(100,0 \%)$ memiliki keaktifan siswa dalam belajar yang berada pada kategori Sedang. Akan tetapi hasil pada kelompok eksperimen menunjukkan perbedaan yang signifikan ini bisa dilihat bahwamayoritas menunjukkan 22 siswa $(100,0 \%)$ memiliki keaktifan siswa dalam belajar yang berada pada kategori Sangat Tinggi.

\section{Uji Persyaratan Analisis}

Tingkat kesalahan (taraf signifikan) yang digunakan dalam penelitian ini sebesar 0,05 . Uji persyaratan analisis ini bertujuan untuk mengetahui ada penyimpangan atau gangguan atau tidak terhadap variabel-variabel yang ada dalam model. Berikut ini beberapa uji persyaratan yang dilakukan antara lain:

\section{Uji Normalitas}

Uji normalitas dalam penelitian ini menggunakan one sample kolmogorov-smirnov. Untuk mengetahuinormal tidaknya data dapat diketahui dari besarnya nilai $\mathrm{p}$ hitung pada setiap variabel yang akan diteliti. Kriteria pengujian apabila nilai asymp.sig $(2$ tailed $) \geq 0,05$ maka data berdistribusi normal. Sebaliknya apabila nilai asymp.sig 2 tailed $) \leq 0,05$ maka data tidak berdistribusi normal.

Tabel berikut merupakan hasil uji normalitas dari beberapa variabel dalam penelitian ini:

Hasil Uji Normalitas

\begin{tabular}{|c|c|c|c|c|}
\hline Kolomnlr & Variobl & Dorlolrun & Kolmogorov & Signifikasi \\
\hline Кеlompoк & V ariabel & Perlakuan & Smirmov & (p) \\
\hline Kontrol & $\begin{array}{l}\text { Keaktifan } \\
\text { Belajar }\end{array}$ & & 1,147 & 0,144 \\
\hline \multirow{2}{*}{ Eksperimen } & Keaktifan & & \multirow{2}{*}{0,740} & \multirow{2}{*}{0,645} \\
\hline & Belajar & & & \\
\hline
\end{tabular}

\section{Sumber : Data diolah}

Hasil Uji Normalitas dapat dilihat bahwa data dari variabel keaktifan belajar maupun hasil belajar pada kelompok kelas kontrol dan eksperimen memiliki nilai signifikansi (p) lebih besar 0,05 maka data penelitian tersebutdinyatakan berdistribusi normal. Data penelitian telah memenuhi asumsi normalitas sehingga dapat dilanjutkan ke analisis selanjutnya.

\section{Uji Homogenitas}

Uji Homogenitas dilakukan untuk menguji kesamaan dari beberapa bagian sampel. Uji homogenitas ini dilakukan dengan menghitung nilai pretest dengan nilai pretest antara kedua kelompok dan antara 
nilai posttest dengan nilai posttest antara kedua kelompok pula. Dalam menguji homogenitas data menggunakan uji normalitas dengan bantuan program komputer SPSS 21.0 for windows ketentuan jika sig. > 0,05 maka data tersebut homogen.

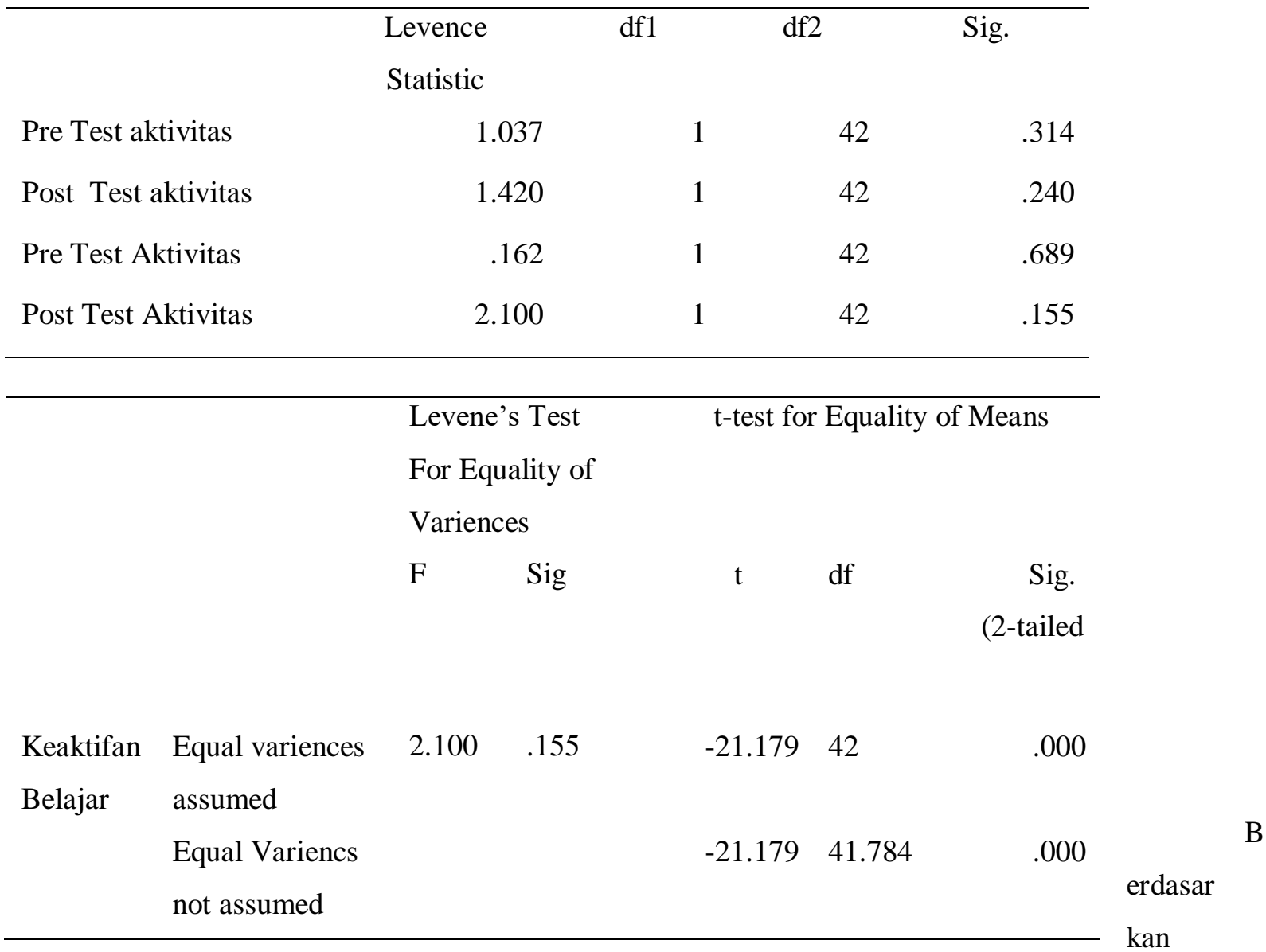

ujihomogenitas dapat dilihat bahwa nilai LeveneStatistic pada variabel Keaktifan Belajar Siswa pre test dan post testdengan taraf signifikansi sebesar 0,689 dan 0,155 berarti lebih besar dari 0,05 maka dapat dikatakan data keaktifan belajar siswa homogen, berarti asumsi homogenitas telah terpenuhi. Data keaktifkan belajar dan hasil belajar telah memenuhi asumsi normalitas dan homogenitas, sehingga dapat dilanjutkan analisis statisik paramaterik selanjutnya.

\section{Uji Independentt Test}

Uji $\mathrm{t}$ (independentsample $t$ test) untuk mengetahui apakah pembelajaran menggunakan model pembelajaran TTW lebih baik dari pada model pembelajaran konvensional. serta untuk menjawab dari tujuan dalam penelitian ini : (1) Untuk mengetahui perbedaan keaktifan siswa yang diberikan pembelajaran dengan menggunakam model kooperatif tipe TTW dan pembelajaran Konvensional dalam proses mata pelajaran Matmatika siswa kelas IV di sekolah dasar.; dan (2) Untuk mengetahui pengaruh model pembelajaran kooperatif tipe TTW terhadap hasil belajar siswa dalam proses pembelajaran mata pelajaran IPS siswa kelas IV di Sekolah Dasar.

\section{Pengujian Hipotesis}

Setelah dilakukan uji persyaratan analisis, langkah selanjutnya adalah melakukan analisis data. Teknik analisis data yang digunakan pada penelitian ini adalah uji beda independent $t$ test, 
digunakan untuk menguji hipotesis pertama yang berbunyi "Ada perbedaan keaktifan siswa yang diberikan pembelajaran dengan menggunakam model kooperatif tipe TTW dan pembelajaran Konvensional dalam proses mata pelajaran IPS siswa kelas IV di sekolah dasar". Berikut merupakan hasil analisis statistik uji independent $t$ test dengan menggunakan SPSS 21.0:

\section{Hasil Uji T Keaktifan siswa}

Group Statistics

\begin{tabular}{llcrrr}
\hline & Kelompok & N & Mean & \multicolumn{1}{l}{$\begin{array}{l}\text { Std. } \\
\text { deviation }\end{array}$} & \multicolumn{1}{l}{$\begin{array}{l}\text { Mtd. Error } \\
\text { Keaktifan }\end{array}$} \\
Belajar & Kontrol & 22 & 47.1009 & 7.29613 & 1.55554 \\
& & & & & \\
& Eksperimen & 22 & 94.1214 & 5.78863 & 1.44734 \\
\hline
\end{tabular}

\section{Independent sample test}

\section{Sumber : Data yang sudahdiolah}

Hasil analisis menunjukkan jumlah data valid ada 44 terdiri dari 22 siswa kelas kontrol dan 22 siswa kelas eksperimen. Nilai rata-rata 47.1009 pada kelas kontrol dan 92.1214 pada kelas eksperimen.

Pada hasil analisis dengan uji independent sample $T$ test, dari nilai rata-rata tersebut, dapat dikatakan adanya perbedaan Keaktifan Belajar Siswa antara kelas kontrol dan kelas eksperimen, diperkuat oleh hasil uji $\mathrm{t}$ yaitu nilai $\mathrm{t}_{\text {hitung }}=-21,179$ dengan tingkat signifikan (sig) kurang dari $5 \%$. Hal ini membuktikan bahwa ada perbedaan Keaktifan Belajar Siswa yang signifikan antara kelompok kelas kontrol dan eksperimen dengan kata lain terdapat pengaruh model pembelajaran kooperatif tipe TTW terhadap keaktifan siswa dalam proses pembelajaran mata pelajaran Matematika siswa kelas IV di Sekolah Dasar, sehingga hipotesis yang berbunyi : "Adakah perbedaan keaktifan siswa yang diberikan pembelajaran dengan menggunakam model kooperatif tipe TTW dan pembelajaran Konvensional dalam proses mata pelajaran Matematika siswa kelas IV di sekolah dasar." telah terbukti.

\section{SIMPULAN DAN SARAN}

Berdasarkan penelitian yang telah dilaksanakan dan uji perbedaan dengan Uji bedaIndependent $t$ Test, maka disimpulkan bahwa keaktifan belajar siswa kelas kontrol dan eksperimen terdapat pebedaan signifikan, ini bisa dilihat dari uji t yaitu nilai $t_{\text {hitung }}=-21,179$ dengan tingkat signifikan (sig) kurang dari 5\%. Sehingga, dapat disimpulkan bahwa terdapat perbedaan yang signifikan antara model pembelajaran tipe think talk write (TTW) dan Konvensional sehingga berpengaruh terhadap keaktifan siswa dalam pembelajaran Matematika. Berdasarkan kesimpulan penelitian model pembelajaran pembelajaran kooperatif tipe TTW (Think Talk Write)berpengaruh terhadap hasil belajar dan Keaktifan Belajar siswa Kelas IV SDM 020 Kuok maka saran untuk peneliti selanjutya. Untuk pengaruh model pembelajaran kooperatif tipe think talk write terhadap keaktifan Siswa, peneliti selanjutya bisa menambahkan dengan pengembangan media yang bisa menimbulkan keaktifan siswa. 


\section{DAFTAR PUSTAKA}

Acar, Filiz Evran. 2008. An Assessment of Social Studies Competency of Turkish Classroom Teachers.Journal of Instruction, Vol. 1, No.2.

Astuti, Astuti. Pengaruh Model Pembelajaran Kooperatif Tipe Two Stay Two Stray (Tsts) Terhadap Hasil Belajar Matematika Siswa Kelas Vii Smp Negeri 2 Bangkinang Kota. Jurnal Cendekia : Jurnal Pendidikan Matematika, [S.L.], N. 2, P. 11-28, Oct. 2016. Issn 2579-9258

Ahmadi, Lif Khoiru dan Amri, Sofan. 2011. Mengembangkan Pembelajaran IPS Terpadu. Jakarta: Prestasi Pustaka.

Amri, Sofan. 2013. Pengembangan dan Model Pembelajaran dalam Kurikulum 2013. Jakarta: Prestasi Pustaka.

Arikunto, Suharsimi. 2010. Prosedur Penelitian Suatu Pendekatan Praktik. Jakarta: Rineka Cipta.

Aqip, Zainal, dkk. 2009. Penelitian Tindakan Kelas untuk Guru SD, SLB, dan TK. Bandung: CV. Yrama Widya.

Aunurrahman. 2009. Belajar dan Pembelajaran. Bandung: Alfabeta.

Depdiknas.2006. Kurikulum Tingkat Satuan Pendidikan.Jakarta: Depdiknas.

Djamarah, Syaiful,dkk. 2010. Strategi Belajar Mengajar. Jakarta: Rineka Cipta.

Dimyati dan Mudjiono.2010, Belajar dan Pembelajaran. Jakarta: Rineka Cipta.

Gunawan, Rudi. 2011. Pendidikan IPS Filosofi:konsep dan Aplikasi. Bandung Alfabeta.

Hamalik, Oemar. 2011. KurikulumdanPembelajaran. Jakarta: Bumi Aksara

Hidayat, Adityawarman. Pengaruh Problem Based Learning Dengan Pendekatan Problem Solving Dan Self Efficacy Terhadap Hasil Belajar Matematika Siswa Smp Negeri 1 Rumbio Jaya. Jurnal

Cendekia : Jurnal Pendidikan Matematika, [S.L.], N. 2, P. 1-10, Mar. 2018. Issn 2579-9258

Indarti, Titik. 2008. Penelitian Tindakan Kelas (PTK) dan Penulisan Ilmiah. Surabaya: Lembaga Penerbit FBS UNESA.

Jack C. Richard and Theodore S. Rodger. 2001. Approaches and Method In Language Teaching, Amerika: Cambridge University Press.

Jarolimek, John. 1982. Social Studies in Elementary Educations. New York: Macmilian Publishing Company.

Jihad, Aseo dan Haris, Abdul. 2012. Evaluasi Pembelajaran. Yogyakarta: Multi Pressindo.

Jones, Vernon.F with Louises S.Jones. 1998. Comprehensive: Classroom Management. USA: A Viacom Company.

Kemp. Jerold.E,dkk.1994. Designing Effective Instruction.USA: Macmioon College Publishing Company. 
Slameto, 2010.Belajar dan Faktor-Faktor yang Mempengaruhinya.Jakarta. Rineka Cipta.

Sudjana.Nana.2012. Penilaian Hasil Proses Belajar Mengajar.Bandung: PT Remaja Rosdakarya

Sugiyono.2012. Metode Penelitian Kuantitatif dan Kualitatif dan R\&D. Bandung: Penerbit Alfabeta.

Suprijono, Agus. 2009. Cooperative Learning: Teori dan Aplikasi Paikem. Yogyakarta: Pustaka Pelajar.

Susanto, Ahmad. 2013. Pengembangan Pembelajaran IPS di Sekolah Dasar. Jakarta: Kencana.

Trianto. 2010. Model-Model Pembelajaran Inovatif Berorientasi Konstruktivistik. Jakarta. Prestasi Pustaka.

Usman, M. Uzer. 2009. Statistik Dalam Penelitian Psikologi \& Pendidikan. Malang: UMM Press.

Wrech, Jason.S,dkk. 2009. Communication, Afftect and Learning in The Classroom. California: Creative Common Atribut

Zulfah, Zulfah. Analisis Kesalahan Peserta Didik Pada Materi Persamaan Linear Dua Variabel Di Kelas Viii Mts Negeri Sungai Tonang. Jurnal Cendekia : Jurnal Pendidikan Matematika, [S.L.], V. 1, N. 1, P. 1-5, May 2017. Issn 2579-9258

Zulfah, Zulfah. Pengaruh Penerapan Model Pembelajaran Kooperatif Tipe Think Pair Share Dengan Pendekatan Heuristik Terhadap Kemampuan Pemecahan Masalah Matematis Siswa Mts Negeri Naumbai Kecamatan Kampar.Jurnal Cendekia : Jurnal Pendidikan Matematika, [S.L.], N. 2, P. 65-76, Mar. 2018. Issn 2579-9258 